\title{
A systematic review of physical activity promotion in primary care office settings
}

\author{
C B Eaton, L M Menard
}

\begin{abstract}
Objective-To assess the efficacy of physical activity promotion in primary care office settings.

Design-Systematic review of clinical trials in which the efficacy of physical activity promotion was investigated in a primary care office setting with at least one month of follow up.

Subjects-A total of 13981 adults, aged 17-85+, were included from 203 practices in eight trials assessing physical activity promotion in primary care office settings. Main outcome measures-Odds ratios and $95 \%$ confidence intervals were calculated comparing the number of participants who increased their physical activity or were active at follow up in the intervention group with a control group for each study.

Results-Five of eight trials where positive with statistically significant results (range 0.91-6.56), but significant biases or limited clinical relevance of the outcomes were found in all trials. Short term trials of less than one year (four of four were positive), single-risk-factor trials (three of three were positive), randomised clinical trials (two of three were positive), and those assessing moderate levels of physical activity (three of four were positive) were most likely to find benefit. Only one of four trials lasting longer than a year were positive.

Conclusion-There is limited evidence from well designed trials that office based physical activity promotion in primary care settings is efficacious in promoting changes in physical activity that could conceivably have lasting clinical benefits. (Br f Sports Med 1998;32:11-16)
\end{abstract}

Keywords: physical activity promotion; primary care; sedentary lifestyles

Brown University School of Medicine, Department of Family Medicine, Memorial Hospital of Rhode Island, Pawtucket, RI 02860, USA

C B Eaton

L M Menard

Correspondence to: Dr C B Eaton

Accepted for publication 2 October 1997 daemia as a risk factor for cardiovascular disease. ${ }^{14}$ Public health officials in the United States and Great Britain have recognised the importance of physical activity and have recently published a health message that "every adult should accumulate 30 minutes or more of moderate-intensity physical on most days of the week." ${ }^{8}$ Despite this message, most of the British (70\%) and American population (60\%) remain sedentary. ${ }^{19}$

One potential way of increasing physical activity in the population is for primary care doctors or general practitioners to provide counselling in their offices with regard to physical activity. Most of the population of the United States and Great Britain visit a general practitioner or primary care doctor at least once every two years. ${ }^{10}$ Thus office based counselling on physical activity has the potential to be an important preventive strategy if performed effectively.

The purpose of this systematic review is to answer the following questions. (1) What is the quality of the evidence that physical activity counselling in primary care office practice is efficacious? (2) If efficacious, how generalisable are these results to normal primary care office practice?

\section{Methods}

SEARCH METHODS

Computerised searches were carried out using Medline, Dialog(R) of Dissertation Abstracts, Sci Li Reference from 1961 to 1997. Keywords for searching included exercise, physical fitness, trials, meta-analysis, and outcome assessment. The search was limited to the English language. Additional searches were carried out using papers identified in the search and from previous reviews. In addition, content experts in the field were asked to provide additional published or unpublished studies.

\section{DATA EXTRACTION}

Papers were reviewed if they met the following criteria: (1) a control group had to exist; (2) subjects had to be assigned to a control group or intervention status; (3) interventions had to be performed in the doctor's office practice and not at homes, worksites, churches, or community organisations; (4) exercise behaviour had to be assessed a minimum of four weeks after the intervention and had to be interpretable as a dichotomous variable so that odds ratios (ORs) could be calculated. The following factors were evaluated in each study by two independent reviewers: study design, practice location, number of study subjects, recruitment rate, number of practices, practice intervention, patient intervention, duration of the study, year of the study, physical activity at baseline and after the intervention, selection 
Table 1 Clinical trials of physical activity promotion in primary care offices

\begin{tabular}{|c|c|c|c|c|}
\hline Article & Study design & Randomised trial & Practice & Study \\
\hline $\begin{array}{l}\text { INSURE } 1984 \\
\text { Wisconsin, } \\
\text { Pennsylvania, Florida }\end{array}$ & $\begin{array}{l}\text { Quasiexperimental; } \\
\text { multiple behaviours; } \\
\text { one year follow up }\end{array}$ & No; volunteer practices & $\begin{array}{l}5 \text { multispecialty group } \\
\text { practices ( } 72 \\
\text { physicians) }\end{array}$ & $\begin{array}{l}\text { Exp }=203, \text { control = } \\
83 \text {; age } 18-75+\text {; men } \\
\text { and women }\end{array}$ \\
\hline $\begin{array}{l}\text { Kelly } 1987 \\
\text { Cleveland, Ohio }\end{array}$ & $\begin{array}{l}\text { Quasiexperimental; } \\
\text { multiple behaviours; } 6 \\
\text { week follow up }\end{array}$ & $\begin{array}{l}\text { No; control group a } \\
\text { random sample of } \\
\text { non-participants } \\
\text { because of office } \\
\text { scheduling with } \\
\text { non-physician provider }\end{array}$ & $\begin{array}{l}\text { Single model FP } \\
\text { residency } \\
\text { (18 physicians) }\end{array}$ & $\begin{array}{l}\text { Exp }=134, \text { control }= \\
58 ; \text { age } 18-60 ; \text { men and } \\
\text { women }\end{array}$ \\
\hline $\begin{array}{l}\text { PACE } 1996 \text { San } \\
\text { Diego County }\end{array}$ & $\begin{array}{l}\text { Quasiexperimental; } \\
\text { stage of change } \\
\text { approach to physical } \\
\text { activity; } 4-6 \text { week follow } \\
\text { up }\end{array}$ & No; volunteer practices & $\begin{array}{l}17 \text { volunteer primary } \\
\text { care physician offices }\end{array}$ & $\begin{array}{l}\text { Exp }=98, \text { control }= \\
114 ; \text { age }>18 ; \text { men and } \\
\text { women free of coronary } \\
\text { heart disease }\end{array}$ \\
\hline $\begin{array}{l}\text { Johns Hopkins } \\
\text { Medicare Preventive } \\
\text { Services } \\
\text { Demonstration } \\
\text { Project } 1989 \text { Eastern } \\
\text { Baltimore }\end{array}$ & $\begin{array}{l}\text { Randomised clinical } \\
\text { trial; } 1 \text { year follow up }\end{array}$ & $\begin{array}{l}\text { Yes; patients } \\
\text { randomised to } \\
\text { preventive health exams }\end{array}$ & $\begin{array}{l}3 \text { hospital clinics, } 13 \\
\text { community group } \\
\text { practices, } 103 \\
\text { solo/partnership } \\
\text { practices }\end{array}$ & $\begin{array}{l}1573 \text { intervention; } 1524 \\
\text { controls. Medicare } \\
\text { benefciaries age } 65 \text { and } \\
\text { older; } 32.6 \% \text { sedentary } \\
\text { with good health and } \\
72.9 \% \text { with poor health }\end{array}$ \\
\hline $\begin{array}{l}\text { Physician } \\
\text { Advice1991Colorado }\end{array}$ & $\begin{array}{l}\text { Quasiexperimental; } 1 \\
\text { month follow up }\end{array}$ & $\begin{array}{l}\text { No; both groups with } \\
\text { high frequency of advice }\end{array}$ & $\begin{array}{l}24 \text { residents, academic } \\
\text { family practice }\end{array}$ & $\begin{array}{l}82 \text { advice; } 111 \text { no } \\
\text { advice group. age } 18+; \\
\text { scheduled patients }\end{array}$ \\
\hline $\begin{array}{l}\text { Oxcheck 1989-92 } \\
\text { Bedfordshire, } \\
\text { England }\end{array}$ & $\begin{array}{l}\text { Randomised clinical } \\
\text { trial; } 3 \text { year follow up }\end{array}$ & $\begin{array}{l}\text { Yes; patients } \\
\text { randomised }\end{array}$ & $\begin{array}{l}5 \text { urban general } \\
\text { practices }\end{array}$ & $\begin{array}{l}2205 \text { study } \\
\text { patients; } 1916 \text { controls; } \\
\text { age } 35-64 ; \text { men and } \\
\text { women }\end{array}$ \\
\hline $\begin{array}{l}\text { Green Prescription } \\
\text { Auckland and } \\
\text { Dunedin New } \\
\text { Zealand }\end{array}$ & $\begin{array}{l}\text { Randomised clinical } \\
\text { trial; } 6 \text { week follow up }\end{array}$ & $\begin{array}{l}\text { Yes, but convenience } \\
\text { sample of sedentary } \\
\text { patients assessed to } \\
\text { most likely benefit and } \\
\text { succeed over the next } 6 \\
\text { weeks in increasing } \\
\text { physical activity }\end{array}$ & 37 general practices & $\begin{array}{l}218 \text { intervention group } \\
\text { of written prescription; } \\
238 \text { verbal advice only } \\
\text { for subjects with less } \\
\text { than } 1 \text { hour of vigorous } \\
\text { activity or } 3 \text { hours of } \\
\text { moderate activity a } \\
\text { week }\end{array}$ \\
\hline $\begin{array}{l}\text { Leeds Yorkshire and } \\
\text { SW Thames UK } \\
1992\end{array}$ & $\begin{array}{l}\text { Quasiexperimental; } 1 \\
\text { and } 2 \text { year follow up }\end{array}$ & $\begin{array}{l}\text { No; } 12 \% \text { sample was } \\
\text { chosen for health check }\end{array}$ & 18 general practices & $\begin{array}{l}1687 \text { intervention } \\
\text { group; } 3937 \text { control } \\
\text { group. }\end{array}$ \\
\hline
\end{tabular}

CI, confidence interval.

bias, measurement error of outcome variable, confounding bias, competing interventions, generalisability of results.

STATISTICAL METHODS

Two by two tables were generated comparing physically active with sedentary subjects for intervention and control groups in each study. ORs were calculated comparing the odds of the intervention group increasing physical activity or being active at follow up with those of a control group. The $95 \%$ confidence intervals (CI) were calculated using the formula, anti-log $\left(\log _{\mathrm{e}} \mathrm{OR}+1.96 \mathrm{SE}\right)$, where the standard error $(\mathrm{SE})=(1 / \mathrm{A}+1 / \mathrm{B}+1 / \mathrm{C}+1 / \mathrm{D})^{1 / 2}$ for a standard two by two table. ${ }^{11} \mathrm{~A}$ summary OR using meta-analytical techniques was not determined because of the small number of studies and the large degree of heterogeneity between studies, making summary estimates of effect misleading.

\section{Results}

Over 20 potentially relevant articles were reviewed. Eight clinical trials met the inclusion criteria, and the results are tabulated in table 1 and described below. Most studies used different methodologies in terms of recruitment of patients and practices, interventions, outcome measures, and methods of analyses and are discussed below.

The INSURE (Industry-wide Network for Social, Urban and Rural Efforts) study performed in 1984 was a prospective study of 2218 adults (1409 study subjects and 809 controls) and used a quasi-experimental design to determine if the health risk behaviours of patients had changed one year after preventive intervention by primary care doctors. ${ }^{12}$ Three of six multispecialty practices and two of five control practices agreed to participate in the study, and $74-100 \%$ of the primary care 
Table 1 continued

\begin{tabular}{|c|c|c|c|c|}
\hline Practice intervention & Patient intervention & Outcome & Odds ratio $(95 \%$ CI) & Comments \\
\hline $\begin{array}{l}\text { CME seminars; review } \\
\text { protocols, discuss problems }\end{array}$ & $\begin{array}{l}15 \text { minute patient education } \\
\text { and risk factor counselling }\end{array}$ & $\begin{array}{l}\text { Self reported started vigorous } \\
\text { exercise at least once a week } \\
\text { using unvalidated telephone or } \\
\text { postal questionnaire }\end{array}$ & $\begin{array}{l}1.39(0.99 \text { to } 1.96) \text {; total } \\
\text { study; } 1.65(1.12 \text { to } 2.43) \\
\text { post hoc treated only }\end{array}$ & $\begin{array}{l}\text { External validity questionable } \\
\text { as only } 28 \% \text { of sample } \\
\text { responded;unit of intervention } \\
\text { practice, unit of analysis } \\
\text { patient. }\end{array}$ \\
\hline $\begin{array}{l}\text { Physician education on } \\
\text { lifestyle prescription form, } \\
\text { and education materials }\end{array}$ & $\begin{array}{l}\text { Lifestyle assessment, } \\
\text { educational materials, booster } \\
\text { phone calls }\end{array}$ & $\begin{array}{l}\text { Self reported making some or } \\
\text { significant change in exercising } \\
\text { using unvalidated question on } \\
\text { telephone follow up } 4 \text { weeks } \\
\text { after intervention. }\end{array}$ & $2.84(1.49$ to 5.42$)$ & $\begin{array}{l}\text { Potential selection bias with } \\
\text { use of non-participants as } \\
\text { control group. Benefits of } \\
\text { "some change" in exercise not } \\
\text { clear. }\end{array}$ \\
\hline $\begin{array}{l}\text { Physician manual, physician } \\
\text { role playing with trainer for } \\
\text { two visits }\end{array}$ & $\begin{array}{l}\text { Stages of change assessment; } \\
3-5 \text { minutes of counselling, } \\
\text { physician recommendations, } \\
10 \text { minute booster phone call }\end{array}$ & $\begin{array}{l}\text { Self reported stage of change } \\
\text { and physical activity using } \\
\text { validated walking question and } \\
\text { overall activity; subsample with } \\
\text { Caltrac accelerometer; by } \\
\text { telephone interview } 4-6 \text { weeks } \\
\text { after intervention }\end{array}$ & $\begin{array}{l}6.56 \text { ( } 4.61 \text { to } 9.33) \text { moving } \\
\text { from contemplation to active } \\
\text { stage; intervention increased } \\
\text { walking } 37 \text { minutes/week } \\
\text { compared with } 7 \text { minutes/week } \\
\text { for controls. }\end{array}$ & $\begin{array}{l}\text { Volunteer physicians; } 52 \% \text { of } \\
\text { eligible patients evaluated. } \\
\text { Intervention group while } \\
\text { increasing only average } 11 \\
\text { minutes/day of exercise } \\
\text { compared with } 30 \text { minutes/day } \\
\text { recommended. }\end{array}$ \\
\hline $\begin{array}{l}\text { Orientation sessions with } \\
\mathrm{CME} \text { credits on preventive } \\
\text { exams and counselling visits }\end{array}$ & $\begin{array}{l}\text { Two preventive exams a year } \\
\text { apart reviewing lifestyle risk } \\
\text { assessment and reimbursed } \\
\text { follow up counselling within } 6 \\
\text { months; controls received } \\
\text { usual care. }\end{array}$ & $\begin{array}{l}\text { Self reported performance of } \\
\text { physical activities such as } \\
\text { walking, gardening, or heavy } \\
\text { housework less than three } \\
\text { times/week }\end{array}$ & $\begin{array}{l}1.04^{\star}(0.78 \text { to } 1.39) \text { good } \\
\text { health; } 1.17^{\star}(0.69 \text { to } 1.97) \\
\text { poor health; }{ }^{\star} \text { adjusted for age, } \\
\text { gender, race, marital status, } \\
\text { health status }\end{array}$ & $\begin{array}{l}\text { Well designed, large sample } \\
\text { size, multiple interventions, PA } \\
\text { discussed in } 89 \% \text { of preventive } \\
\text { visits; } 70 \% \text { of intervention } \\
\text { patients had preventive visits }\end{array}$ \\
\hline $\begin{array}{l}15 \text { minutes of physician } \\
\text { training on protocol }\end{array}$ & $\begin{array}{l}2-3 \text { minutes of exercise advice, } \\
\text { educational handout, } 1 \text { month } \\
\text { follow up }\end{array}$ & $\begin{array}{l}\text { Self reported activity levels, } \\
\text { frequency and duration at } \\
\text { baseline and one month } \\
\text { telephone follow up }\end{array}$ & $\begin{array}{l}1.91 \text { ( } 1.25 \text { to } 2.94) \text {; increase of } \\
109 \text { minutes/week in advice } \\
\text { group compared with decrease } \\
\text { of } 24 \text { minutes/week in no } \\
\text { advice group }\end{array}$ & $\begin{array}{l}\text { Randomised control trial } \\
\text { abandoned because of high } \\
\text { percentage of advice in contro } \\
\text { physicians; biased sample with } \\
80 \% \text { of patients at baseline } \\
\text { exercising }\end{array}$ \\
\hline $\begin{array}{l}\text { Nurse trained in patient } \\
\text { centred communication } \\
\text { model during } 2 \text { day course, } \\
\text { annual study day, monthly } \\
\text { evening training sessions }\end{array}$ & $\begin{array}{l}1 \text { hour nurse health check } \\
\text { including lifestyle evaluation } \\
\text { and } 10-20 \text { minute follow up } \\
\text { appointments }\end{array}$ & $\begin{array}{l}\text { Self reported vigorous exercise } \\
\text { less than once a month at } \\
\text { baseline and } 3 \text { years later }\end{array}$ & $\begin{array}{l}1.19(1.11 \text { to } 1.27) \text {; attenders } \\
\text { only } 1.25 \text { (1.16 to } 1.34)\end{array}$ & $\begin{array}{l}\text { Mutiple risk factor } \\
\text { intervention; health benefits of } \\
\text { increased vigorous exercise to } \\
>\text { once/month unclear; } \\
\text { significant time spent on } \\
\text { recruiting patients limit } \\
\text { practicality. }\end{array}$ \\
\hline $\begin{array}{l}\text { Training session of GPs to } \\
\text { assess and prescribe physical } \\
\text { activity }\end{array}$ & $\begin{array}{l}\text { Assessment and advice of } \\
\text { about } 5 \text { minutes with written } \\
\text { prescription of exercise }\end{array}$ & $\begin{array}{l}\text { Self reported time spent over } \\
\text { the preceding } 2 \text { weeks in } \\
\text { walking, sport, or leisure time } \\
\text { activities measured at baseline } \\
\text { by personal interview and at } 6 \\
\text { weeks by telephone interview }\end{array}$ & $\begin{array}{l}1.81(1.42 \text { to } 2.32) \text {; increase of } \\
156 \mathrm{~min} / 2 \text { week period in the } \\
\text { green experimental group }\end{array}$ & $\begin{array}{l}\text { Patients and GPs selected for } \\
\text { high compliance; most } \\
\text { intervention and control } \\
\text { groups did not reach goal of } \\
30 \text { minutes of walking } 5 \text { days } \\
\text { per week }\end{array}$ \\
\hline None & Health check up by GP & $\begin{array}{l}\text { Self reported vigorous activity } \\
\text { in the previous } 2 \text { weeks at } \\
\text { baseline and } 2 \text { years later using } \\
\text { mailed questionnaires }\end{array}$ & $\begin{array}{l}0.91(0.83 \text { to } 0.99) \text { health } \\
\text { check in past } 2 \text { years; health } \\
\text { check in past } 12 \text { months } 1.0 \\
(0.95 \text { to } 1.05)\end{array}$ & $\begin{array}{l}\text { Multiple risk factor } \\
\text { intervention; } 75 \% \text { compliance } \\
\text { with health check up; } 75 \% \text { of } \\
\text { respondents had no vigorous } \\
\text { exercise in the past two weeks } \\
\text { at survey } 2\end{array}$ \\
\hline
\end{tabular}

doctors from each practice agreed to participate. About $28 \%$ of the random sample of patients were evaluated, with a $61 \%$ rate of response to the initial postal survey, a $57 \%$ rate of response for the initial health examination, and an $80 \%$ rate of response for the follow up appointments. Thus the experimental group consisted of 203 subjects and the control group of 83 subjects. The experimental group received about 15 minutes of education and counselling on risk reduction. At baseline, $55.4 \%$ of the experimental group and $55.3 \%$ of the controls were sedentary. Of these sedentary patients, $31.5 \%$ of those randomised to the intervention group started exercising compared with $24.1 \%$ of the control group. This $39 \%$ increase in vigorous activity in a previously sedentary population fell just short of statistical significance $(p=0.06)$. In a post hoc analysis of patients who actually received the preventive intervention, $33.8 \%$ increased self reported vigorous exercise at least once a week compared with $24.1 \%$ in the control group, and this $65 \%$ increase was found to be statistically significant $(p=0.02)$. Concerns about the external validity of this study because of the use of volunteer practices and the low response rate $(28 \%)$ exist. Measurement error inherent in the use of unvalidated self reported measures of physical activity in this trial would tend to bias the results towards no effect. It is unclear from this trial if the degree of exercise change of $33.8 \%$ of sedentary patients in the intervention group from less than once a week of vigorous exercise to more than once a week has any clinically relevant health benefits.

The "controlled trial of a time-efficient method" of Kelly ${ }^{13}$ was a randomised trial in one family practice residency consisting of three doctors and 15 residents. Several risk 
behaviours were assessed in 412 adults aged 18-60 eligible for health promotion. Sedentary patients defined as exercising less than twice a week $(n=192)$ who received any lifestyle education were compared with those who were non-participants because of office scheduling problems. Those participants who made some change or significant change defined as exercising twice or more a week were compared with those that made no change over a four week interval, as assessed from a structured phone interview. Those in the intervention group were significantly more likely $(\mathrm{OR}=2.84 ; 95 \%$ CI 1.49 to 5.42) than non-participants to increase physical activity. Although this trial is statistically significant, concerns exist about the clinical relevance of some or "significant" change in self reported exercise of more than twice a week after only one month of follow up. In addition, the bias inherent in the selection of the control group leads to questions of internal validity of this study.

The "controlled trial of physician counselling to promote the adoption of physical activity" by Calfas et $a l^{14}$ evaluated a physician based assessment of counselling for exercise protocol using a stage of change model in 17 volunteer primary care doctor's offices in San Diego County. Sedentary patients defined as engaging in vigorous physical activity less than three times a week or moderate activity for less than two hours a week, who were aged over 18 and free of coronary heart disease or other conditions that could limit mobility, were recruited for the study. A $52 \%$ response rate (n $=212$ ) was obtained after four to six weeks of follow up. The intervention focused on increasing moderate levels of physical activity such as walking using a patient centred stage of change approach. Of those patients in the intervention group, $52 \%$ moved from contemplation to the active stage compared with $12 \%$ of the control group $(\mathrm{OR}=6.56 ; 95 \% \mathrm{CI} 4.61$ to 9.33$)$. The intervention group increased their physical activity by 37 minutes a week compared with 7 minutes a week in the control group $(\mathrm{p}<0.05)$. However, at follow up assessment, patients reported walking an average of 11 minutes a day, which has questionable clinically relevant health benefits particularly in the light of the short term follow up noted in this study. In addition, the selection bias of using volunteer practices suggests a best case scenario that may not be applicable to most primary care office practices.

The Johns Hopkins Medicare Preventive Services Demonstration Project ${ }^{15}$ evaluated the effects of preventive examinations on smoking, excessive alcohol drinking, and sedentary lifestyle at baseline and one year later in Medicare beneficiaries in Eastern Baltimore in 1989. This randomised control trial involved 1573 intervention and 1524 control patients from three hospital clinics, 13 community group practices, and 103 solo/partnership practices. Definition of sedentary lifestyle was based on self reported performance of physical activity such as walking, gardening, and heavy housework less than three times a week. During preventive examinations, doctors discussed physical activity in $89 \%$ of the encounters. Compliance with the preventive examinations was good, with $70 \%$ of those randomised to intervention receiving an examination. No statistically or clinically significant increases in physical activity occurred as a result of the intervention with an OR of 1.04 (95\% CI 0.78 to 1.39) for patients with good health and an OR of 1.17 (95\% CI 0.69 to 1.97) for patients in poor health after adjustment for age, gender, race, marital status, and health status. This study reflects a generalisable well designed clinical trial with a large sample size of elderly patients, with little bias or confounding.

The "effect of physician advice on exercise behaviour" study by Lewis and Lynch $^{16}$ was designed as a randomised clinical trial to evaluate the efficacy of a physician advice protocol to increase the frequency and duration of self reported activity levels after one month of follow up. The study location was one family practice residency in Colorado with 24 residents in 1991. Of the 396 patients admitted to the study, $35 \%$ refused to cooperate and $12 \%$ were lost to follow up, resulting in a 53\% response rate. Baseline assessment showed that $70 \%$ of the patients were exercising before the intervention and that a sizable percentage (30$40 \%$ ) of the control group doctors were giving unprompted physical activity promotion advice. For this reason, the investigators adopted a quasi-experimental design and assessed the effect of physician advice (intervention group) versus no advice (control group) on increasing physical activity levels. A statistically significant difference $(\mathrm{OR}=1.91 ; 95 \%$ CI 1.25 to 2.94$)$ was found when those reporting exercising at the end of one month in the physician advice group were compared with the no advice group. This increase appeared to be related to an increase in duration but not frequency of exercise. There are significant concerns about the internal validity of this study's conclusions because of uncontrolled confounding bias resulting from the abandonment of the intent to treat analysis of the study. Also the high rate of exercise, over $70 \%$ at baseline, limits the generalisability of these findings.

OXCHECK ${ }^{17}$ was a randomised control trial focused on the effect of a general health check on several cardiovascular disease and cancer risk behaviours including vigorous exercise; it was performed in Bedfordshire, England, between 1989 and 1992. Nurses trained in patient centred communication performed health checks, including lifestyle assessment, and provided counselling and follow up appointments in five urban general practices. Assessment of 2205 intervention patients and 1916 control patients after three years of follow up showed that $70.9 \%$ of the control group and $67.6 \%$ of the intervention group reported undertaking vigorous exercise less than once a month. These results from this well designed clinical trial with high internal validity and generalisability were statistically significant with $\mathrm{OR}=1.19$ and $95 \%$ CI 1.11 to 1.27 . However, the clinical relevance of a $4.5 \%$ absolute difference when comparing the intervention group with the control group in 
Table 2 Comparison of physical activity promotion trials by selected factors

\begin{tabular}{|c|c|c|c|c|c|c|}
\hline Article & $\begin{array}{l}\text { Randomised } \\
\text { clinical trial }\end{array}$ & $\begin{array}{l}\text { Intervention } \\
\text { physical } \\
\text { activity only }\end{array}$ & $\begin{array}{l}\text { Duration of } \\
\text { followup }\end{array}$ & Outcome measure & $\begin{array}{l}\text { Methodological } \\
\text { flaws }\end{array}$ & Interpretation \\
\hline INSURE & No & No & 1 year & Vigorous activity & Significant & $+/-($ post hoc analysis +$)$ \\
\hline Kelly & No & No & 4 weeks & Exercise & Significant & $++(\mathrm{OR}>2.0)$ \\
\hline PACE & No & Yes & $4-6$ weeks & Walking; validated & Significant & $+++(\mathrm{OR}>5.0)$ \\
\hline Johns Hopkins & Yes & No & 1 year & $\begin{array}{l}\text { Walking, gardening, } \\
\text { household }\end{array}$ & None & $-(\mathrm{OR}=1.0)$ \\
\hline Colorado & No & Yes & 4 weeks & Walking & Significant & $+(\mathrm{OR}>1.0)$ \\
\hline OXCHECK & Yes & No & 3 years & Vigorous activity & None & $+(\mathrm{OR}>1.0)$ \\
\hline \multicolumn{7}{|l|}{ Green } \\
\hline prescription & Yes & Yes & 6 weeks & Walking; validated & Significant & $+(\mathrm{OR}>1.0)$ \\
\hline Leeds & No & No & 1 and 2 years & Vigorous & Significant & $--(\mathrm{OR}<1.0)$ \\
\hline
\end{tabular}

$\mathrm{OR}$, odds ratio.

performing vigorous exercise more than once a month is probably very limited.

The Green Prescription by Swinburn et $a l^{18}$ is a randomised clinical trial that was performed to determine if written advice was more effective at increasing physical activity among selected sedentary patients than verbal advice alone after six weeks of follow up. This study performed in 37 general practices in Auckland and Dunedin, New Zealand, trained general practitioners to assess and prescribe physical activity, focusing on walking as the main intervention. From a convenience sample of sedentary patients defined as undertaking less than one hour of vigorous activity or three hours of moderate activity a week during work or recreation time, who were deemed by their general practitioner to be likely to benefit from enhanced physical activity and who were able to do so over the ensuing six weeks, 218 intervention patients were randomised to written prescription and patient education materials and 238 control patients were only given verbal advice. Assessment and counselling by the doctor lasted on average five minutes. After six weeks of follow up, a statistically significant increase in physical activity $(\mathrm{OR}=1.81 ; 95 \%$ CI 1.42 to 2.32 ) was found in the intervention group ( $85 \%$ active) compared with the group that received verbal advice alone $(76 \%)$. This increase in physical activity averaged 156 minutes per two week period. Long term benefits were assessed by telephone interview only in those that successfully increased activity in the intervention group at 11 months; $59 \%$ had maintained there increased physical activity. Bias inherent in selecting patients during practice consultations convenient to the practitioner rather than a random sample of patients places significant restraints on the generalisability of these findings. While the intervention group significantly increased their level of walking, the absolute levels of walking were greater in the verbal advice group (249 minutes per two weeks) at six weeks than in the intervention group (217 minutes per two weeks). The health benefits of the average level of physical activity for both groups (17 minutes a day of walking) are unclear as it is far below the recommended 30 minutes a day of moderate level activity. Ascertainment bias of the investigators by failing to follow up the control group and those that initially had not increased physical activity may invalidate the results of the 11 month follow up data in this study.
The "prevention in practice" study by Dowell et $a l^{19}$ in Leeds, England, used a quasiexperimental design to compare self reported vigorous exercise in the two weeks before and two years after a health check aimed at changing multiple risk factors for the prevention of stroke and heart disease. A $12 \%$ stratified sample of patients was chosen from 18 general practices in the Yorkshire and Southwest Thames regions, and these patients were invited for a health check, yielding 1687 patients in the intervention group and 3937 patients in the control group without a health check. The investigators found a statistically significant decrease in exercise $(\mathrm{OR}=0.91$; $95 \%$ CI 0.83 to 0.99 ) after two years of follow up in the health check group and a nonsignificant null effect after one year of follow up $(\mathrm{OR}=1.0 ; 95 \%$ CI 0.95 to 1.05$)$. The population was largely sedentary, with $75 \%$ of the respondents reporting no vigorous exercise in the preceding two weeks. Significant concerns about the potential role of confounding bias exist in this study because of its quasiexperimental design.

\section{SYNTHESIS}

In table 2, each study's results are evaluated as either positive or negative on the basis of its OR and $95 \%$ CI. Factors that might explain these differences such as study design, length of follow up, single versus multiple risk factor intervention, type of physical activity measured, and methodological flaws are also tabulated to determine if they are associated with positive results.

Five of eight trials were positive with statistically significant $\mathrm{OR}>1.0$. The $\mathrm{OR}$ ranged from 0.91 to 6.56 but significant biases or limited clinical relevance of the outcomes were found in all trials. Short term trials of less than one year (four of four were positive), single-riskfactor trials (three of three were positive), and randomised clinical trials (two of three were positive) were most likely to find benefit in office based physical activity promotion. Only one of four large trials from primary care practices lasting longer than a year were positive.

\section{Discussion}

There is a large body of evidence from cardiac rehabilitation programmes, worksites, and facility based programmes that highly motivated participants can increase their physical activity and adhere to exercise programmes that 
improve exercise tolerance, cardiac risk factors, and body composition. ${ }^{20-24}$ However, the percentage of the population that participate in such programmes is small, ${ }^{1}$ and it is unlikely that a sizable percentage of the population will participate in such supervised exercise programmes in the near future. The concept that primary care doctors, who provide most of the health care services to most of the population, can by their personal relationship with their patients motivate them to change their sedentary lifestyles remains appealing as an approach to physical activity health promotion. This analysis shows that to date the scientific evidence for the efficacy of such an approach is modest at best. From the reviewed studies it appears that well designed unifactorial intervention studies aimed at increasing moderate activity in a currently sedentary population using an intent to treat analysis with the practice as the unit of analysis as well as intervention are most likely to show a short term increase in physical activity that would be scientifically valid. The failure of long term studies to be effective suggests that long term physical activity changes may require more active follow up programmes such as a reminder phone call system, increased social support - that is, a buddy system - and other incentives, perhaps financial, to be successful. Given the paucity of valid scientific evidence that promotion of physical activity is worthwhile in primary care settings, what is a busy primary care doctor to do? For those who are believers in the exercise hypothesis, it appears that, by selecting sedentary patients with medical conditions for which physical activity improves prognosis or control of the diseasethat is, obesity, diabetes mellitus, hypertension, dyslipidaemia, anxiety, depression, osteoporosis - and who are motivated to change, a five minute personalised activity message, followed by a written prescription for physical activity, such as briskly walking 30 minutes a day, and a daily compliance $\log$ to be returned to the office is a reasonable approach until further studies are completed.

This work was supported in part by a grant from the American Academy of Family Physicians.

1 US Department of Health and Human Services. Physical activity and health: a report of the Surgeon General. Atlanta, GA: US Department of Health and Human Services, Center for Chronic Disease Prevention and Health Promotion, 1996.
2 Paffenbarger RS, Hyde RT, Wing AL, Hsieh CC. Physical activity, all-cause mortality, and longevity of college lumni. $N$ Engl f Med 1986;314:605-13.

3 Eaton CB, Medalie JH, Flocke SA, et al. Self-reported physical activity predicts long-term coronary heart disease and all-cause mortalities: twenty -one-year follow-up of the Israeli ischemic heart disease study. Arch Fam Med 1995;4: 323-9.

4 Eaton CB. Relation of physical activity and cardiovascular fitness to coronary heart disease. Part I. A meta-analysis of the independent relation of physical activity and coronary heart disease. 7 Am Board Fam Pract 1992;5:31-42.

5 Albanes D, Blair A, Taylor PR. Physical activity and risk of Albanes D, Blair A, Taylor PR. Physical activity and risk of
cancer in NHANES I population. Am $\mathcal{F}$ Public Health 1989; cancer in $\mathrm{N}$

6 Taylor CB, Sallis JF, Needle R. The relation of physical activity and exercise to mental health. Public Health Rep 1985;100:195-201.

7 Helmrich SP, Ragland DR, Leung RW, Paffenbarger RS. dependent diabetes mellitus. N Engl Med 1991;325:14752.

8 Secretary of State for Health. The health of the nation: a strategy for health in England. London: HMSO, 1992. (Cmnd 1986.)

9 Activity and Health Research. Allied Dumbar national fitness survey: a report on the activity patterns and fitness levels. Main findings. London: Sports Council and Health Education Authority, 1992.

10 Marcus BH, Goldstein MG, Jette A, et al. Training physicians to conduct physical activity counseling. Prev Med 1997;26: $382-8$.

11 Rothman K (ed). Modern epidemiology. Boston/Toronto: Little, Brown, and Co, 1986:217-21.

12 Lodgsdon DN, Lazaro CM, Meier RV. The feasibility of behavioral risk reduction in primary medical care. $A m \mathcal{F}$ Prev Med 1989;5:249-56.

13 Kelly RB. Controlled trial of a time-efficient method of health promotion. Am f Prev Med 1988;4:200-7.

14 Calfas KJ, Long BJ, Dallis JF, et al. A controlled trial of physician counseling to promote the adoption of physical activity. Prev Med 1966;25:225-33.

15 Burton LC, Paglia MJ, German PS, et al. The effect among older persons of a general preventive visit on three health behaviors: smoking, excessive alcohol drinking, and sedentary lifestyle. Prev Med 1995;24:492-7.

16 Lewis BL, Lynch WD. The effect of physician advice on exercise behavior. Prev Med 1993;22:110-21.

17 Imperial Cancer Research fund OXCHECK study group. Effectiveness of health checks conducted by nurses in primary care: final results of the OXCHECK study. BMF mary care: final result

18 Swinburn B, Walter L, Arroll B, et al. The Green Prescription Study: a randomized controlled trial of exercise prescription in general practice. Am F Public Health 1998 (In Press).

9 Dowell AC, Ochera JJ, Hilton SR, et al. Prevention in practice: results of a 2-year follow-up of routine health promotion interventions in general practice. Fam Pract 1996; 13:357-62.

20 O'Connor GT, Buring JE, Yusuf S, et al. An overview of randomized trials of rehabilitation with exercise after myocardial infarction. Circulation 1989;80:234-44.

21 DeBusk RF, Miller NH, Superko HR, et al. A casemanagement system for coronary risk factor modification manter acute myocardial infarction. Ann Intern Med 1994; 120:721-9.

22 Leon AS, Certo C, Comoss P, et al. Scientific evidence of the value of cardiac rehabilitation services with emphasis on patients following myocardial infarction: section I: exercise, conditioning component (position paper). $f$ Cardpulm Rehabil 1990;10:79-87.

23 Blair SN, Piserchia PV, Wilbur CS, Crowder JH. A public health intervention model for worksite health promotion: impact on exercise and physical fitness in a health promotion plan after 24 months. $¥ A M A$ 1986;255:921-6.

24 Heirich MA, Foote A, Erfurt JC, Konopka B. Work-site physical fitness programs: comparing the impact of physical fitness programs: comparing the impact of
different program designs on cardiovascular risks. $\mathcal{F}$ Occup Med 1993;35:510-17. 